Article (refereed)

Cuevas-Gonzalez, M.; Gerard, F.; Baltzer, H.; Riano, D.. 2008 Studying the change in fAPAR after forest fires in Siberia using MODIS. International Journal of Remote Sensing, 29 (23). 6873-6892. doi:10.1080/01431160802238427

(c) 2008 Taylor \& Francis

This version available at http://nora.nerc.ac.uk/3205/

NERC has developed NORA to enable users to access research outputs wholly or partially funded by NERC. Copyright and other rights for material on this site are retained by the authors and/or other rights owners. Users should read the terms and conditions of use of this material at http://nora.nerc.ac.uk/policies. html\#access

This document is the author's final manuscript version of the journal article, incorporating any revisions agreed during the peer review process. Some differences between this and the publisher's version remain. You are advised to consult the publisher's version if you wish to cite from this article.

http://www.tandf.co.uk/journals 


\section{Studying the change in fAPAR after forest fires in Siberia using MODIS}

Running Title: Post-fire fAPAR Response of Boreal Forests

María Cuevas-González ${ }^{1,2}$, France Gerard ${ }^{* 1}$, Heiko Balzter ${ }^{3}$, David Riaño ${ }^{4,5}$

${ }^{1}$ Centre for Ecology and Hydrology Monks Wood, Abbots Ripton, Huntingdon, Cambridgeshire, PE28 2LS. UK,

${ }^{2}$ Departamento de Geografía, Universidad de Alcalá, Colegios 2, E-28801, Alcalá de Henares, Madrid. Spain,

${ }^{3}$ Department of Geography, University of Leicester, University Road, Leicester, LE1 7RH, UK,

${ }^{4}$ Center for Spatial Technologies and Remote Sensing (CSTARS), University of California, 250-N, The Barn, One Shields Avenue, Davis, CA 95616-8617, USA.

${ }^{5}$ Centro de Ciencias Humanas y Sociales, Consejo Superior De Investigaciones Científicas (CSIC), C/ Albasanz 26-28, E-28037, Madrid. Spain.

Correspondence: France Gerard, Centre for Ecology and Hydrology Monks Wood, Abbots Ripton, Huntingdon, Cambridgeshire, PE28 2LS. UK, tel: +44 1487 772482, fax:+44 1487 773467, e-mail: $\underline{\text { ffg@,ceh.ac.uk }}$ 


\begin{abstract}
Disturbance events such as fire have major effects on forest dynamics, succession and the carbon cycle in the boreal biome. This paper focuses on establishing whether characteristic spatio-temporal patterns of the fraction of Absorbed Photosynthetically Active Radiation (fAPAR) occur in the initial two years after a fire event in Siberian boreal forests. Time-series of MODIS fAPAR were used to study post-fire dynamics during the year of the fire and the following two years. Three forest types (evergreen needle-leaf, deciduous needle-leaf and deciduous broadleaf) grouped in three latitudinal regions, ranging from $51^{\circ} \mathrm{N}$ to $65^{\circ} \mathrm{N}$, were studied by analysing a sample of fourteen burned areas. For each of the burned areas an adjacent unburned control plot was selected with the aim of separating inter-annual variations caused by climate from changes in fAPAR behaviour due to a burn. The results suggest that (i) the forest types exhibit characteristic fAPAR change trajectories shortly after the fire, (ii) the differences in the fAPAR trajectories are related to the forest type, (iii) fAPAR changes are not significantly different among the latitudinal regions, and (iv) the limited temporal variability observed among the three years of observations indicates that fAPAR varies very little in the initial years after a fire event.
\end{abstract}

Keywords: regeneration, boreal forest, Siberia, fAPAR, wildfires, post-fire, MODIS

\title{
Nomenclature:
}

NDVI = Normalized Difference Vegetation Index

NPP $=$ Net Primary Production

fAPAR $=$ fraction of Absorbed Photosynthetically Active Radiation

MODIS $=$ MODerate resolution Imaging Spectrometer

FDM $=$ Fire Disturbance Map

$\mathrm{ENL}=$ Evergreen Needle-Leaf

$\mathrm{DNL}=$ Deciduous Needle-Leaf

$\mathrm{DBL}=$ Deciduous BroadLeaf

ANOVA $=$ ANalysis Of VAriance 


\section{Introduction}

The boreal forest biome represents the largest continuous forested area of the globe. The forests in this region cover approximately 15 million $\mathrm{km}^{2}$, or about $10 \%$ of the Earth's terrestrial surface. This represents about $33 \%$ of all forested areas in the world (FRA 2000 ) and over $73 \%$ of the world's coniferous forests (ECE/FAO 1985).

The boreal forests play a key role in the Earth's carbon balance because of their extent and the large carbon reserves they contain. To date, scientists have built up evidence suggesting that greenhouse gas induced global warming is occurring. For example, Canada and Russia have recorded a $2^{\circ}-3^{\circ} \mathrm{C}$ temperature increase in the winter and spring over the last 30 years (Environment Canada 1995) and in artic Alaska and western Canada a summer warming of $3^{\circ}-4^{\circ} \mathrm{C}$ has been observed over the last 40 years which has been attributed to the lengthening of the snow-free season (Chapin III et al. 2005). Some of the predicted trends in this region caused by global warming under a doubled $\mathrm{CO}_{2}$ scenario are (1) increased length of fire season (Wotton and Flannigan 1993, Stocks et al. 1998), (2) increased fire weather severity (Flannigan and Van Wagner 1991, Stocks et al. 1998), and (3) increased ignitions from lightning (Fosberg et al. 1990). In fact, Riaño et al. (2007) report that the first impacts of these perturbations can already be seen. They found that burned area has significantly increased during summer in the boreal region between 1981 and 2000. The accelerating fire activity - predicted to increase burned area by $25-50 \%$ over the next century- will have an impact on a wide range of ecosystem processes controlling the storage of carbon in boreal forests (Kasischke 2000).

Changes in vegetation structure influence not only the exchange of greenhouse gases but also albedo and energy partitioning, all of which influence climate feedbacks. In the boreal region, shifts between evergreen and deciduous trees are believed to cause the strongest feedback (Eugster et al. 2000). For example, an increase in fire events increases the proportion of early succession deciduous woods and consequently increases the albedo, decreases heat transfer to the atmosphere and decreases the flammability of boreal forests causing a negative feedback whilst transition to late successional evergreen conifers decreases the winter albedo and is a positive climate feedback (McGuire et al. 2006). In Russian forests, an estimated 40-96\% of total forested area is in some phase of post-fire succession (Rojkov et al. 1996). Russia alone contains about two-thirds of the world's boreal forest, and most of it is present in Siberia. Shvidenko and Nilsson (1994) estimated that over $20 \%$ of the world forested area and $50 \%$ of the world coniferous forested area is located in Siberia. A better understanding of post-fire succession in the Siberian boreal forests will help us to predict the effects of the increasing number of wildfires caused by climate change in these ecosystems, and subsequently forecast the future role of Siberian boreal forests as a carbon sink or source.

Some post-disturbance dynamics studies in boreal forests based on field surveys have been carried out with diverse purposes: (1) studying the effects of fire behaviour on regeneration (Furyaev et al. 2001, Arseneault 2001, Babintseva and Titova 1996, Schimmel and Granström 1996), (2) analysing carbon exchanges of regenerating forests (Meroni et al. 2002, Valentini et al. 2000), (3) investigating forest composition (Johnstone et al. 2004, De Grandpre et al. 2000, Bergeron and Dansereau 1993) and (4) measuring vegetation diversity (Peltzer et al. 2000, Fortin et al. 1999). However, fires in the boreal region are subject to large annual fluctuations which are associated with weather patterns such as low precipitation (Jupp et al. 2006) and high 
temperature. Some estimates indicate that between 5 and 10 million ha of boreal forest burn each year, with most of the area being burned in fires bigger than 50000 ha (Kasischke and French 1997). With such high rates of change in boreal ecosystems, and the remoteness of some burned areas and their huge extent, it is clear that traditional studies of forest succession based on field surveys should be complemented by analyses with remote sensing data which provide timely information on forest ecosystem status for large areas and in a cost efficient manner (Song et al. 2002).

Fire creates profound changes in ecosystems, causing variations in surface reflectance, albedo, moisture and temperature, which can be detected by means of satellite imagery. Satellite imagery can also quantify the annual fluctuations in forest fires, despite the remoteness and large sizes of the burned areas because of its systematic, periodic and global acquisition. Several studies have addressed postdisturbance dynamics using remote sensed imagery with different objectives such as (1) studying the relationships between the time elapsed since fire and the recovery stage (Riaño et al. 2002, Diaz-Delgado and Pons 2001, Henry and Hope 1998, Viedma et al. 1997), (2) studying the effects of fire severity on regeneration (Diaz-Delgado et al. 2003, Jakubauskas et al. 1990), (3) quantifying spatial patterns of post-disturbance vegetation (Schroeder and Perera 2002), (4) mapping successional forest communities (Ustin and Xiao 2001, Steyaert et al. 1997), or (5) mapping the fractional cover of postdisturbance vegetation layers (Vine and Puech 1999). The use of remotely sensed spectral vegetation indices is a common element in many of their methodologies. In these studies various types of vegetation indices have been tested such as the Normalized Difference Vegetation Index (NDVI; Hicke et al. 2003, Diaz-Delgado et al. 2003, Riaño et al. 2002, Ustin and Xiao 2001, Henry and Hope 1998, Steyaert et al. 1997), the Soil Adjusted Vegetation Index (SAVI; Henry and Hope 1998), the Normalized Difference between NIR and SWIR bands (infrared index; Marchetti et al. 1995), and the Structural Index and Tasselled Cap Transformation (Fiorella and Ripple 1993). Other authors have created specific indices to assess the recovery of vegetation. Diaz-Delgado et al. (1998) used unburned control plots (with similar environmental and vegetation conditions like the burned sites to correct for external influences) to calculate the Regeneration Index (RI). Riaño et al. (2002) used this index and also produced the Normalized Regeneration Index (NRI) that takes into account possible microsite differences between plots in terms of total recovery and Diaz-Delgado et al. (2003) produced two new indicators called 'damage' and 'unrecovered_NDVI' to measure fire severity and successful regeneration, respectively, to study their interactions.

In remote sensing studies, post-fire dynamics analyses have been carried out mostly in Mediterranean ecosystems (Diaz-Delgado et al. 2003, Riaño et al. 2002, Henry and Hope 1998, Marchetti et al. 1995). Only a few studied the post-disturbance dynamics in the boreal forest. Hicke et al. (2003) assessed the impact of fire on Net Primary Production (NPP) using a 17-year record of satellite NDVI observations together with a light use efficiency model. NPP is function of a light use efficiency (LUE) coefficient, the fraction of Absorbed Photosynthetically Active Radiation (fAPAR) and the incoming Photosynthetic Active Radiation (PAR). These authors estimated a mean NPP recovery period for boreal forests in Canada of about 9 years, by comparing pre and post-fire observations. Schroeder and Pereira (2002) examined spatial patterns of forest cover in post-fire landscapes over a period of four decades. They found that the time elapsed since the disturbance has a significant effect on the spatial pattern of the vegetation. Recent disturbances have fewer and more aggregated land cover types, and larger and less numerous patches compared to older disturbances. 
Ustin and Xiao (2001) and Steyaert et al. (1997) mapped boreal forests in terms of their regeneration stage.

This study aimed to establish whether recently burned areas in the boreal forests of Siberia show characteristic patterns of post-fire fAPAR as a function of their latitude and forest type. If we are able to determine these patterns, the models for estimating carbon fluxes after disturbances in boreal forests can be improved. Many previous studies on fire effects in boreal forests using remote sensing have focused on monitoring the location and extent of fires and estimating the amount of $\mathrm{CO}_{2}$ directly released through biomass burning. However, for studies of carbon flux it is also necessary to monitor the effects of fire on specific properties, including soil moisture and surface temperature, and ecological processes such as vegetation re-growth (French et al. 1996). fAPAR has been used extensively as a satellite derived intermediate variable for the calculation of surface photosynthesis, evapotranspiration and annual net primary production (Myneni et al. 2003). This study is a first assessment of the suitability of satellite derived fAPAR to understand the behaviour of forest areas one and two years after a fire event.

\section{Material and methods}

\subsection{Study area}

The study area is the SIBERIA-II region (Schmullius and Hese 2002) which is located in the Central Siberian region, stretching from $52-72^{\circ}$ Northern latitude and $88-110^{\circ}$ Eastern longitude (Figure 1). Its 3.2 million $\mathrm{km}^{2}$ area is a mosaic of taiga forest (pine, Pinus sylvestris L.; spruce, Picea obovata Ledeb.; fir, Abies sibirica Ledeb.; larch, Larix sibirica Ledeb.; cedar, Pinus sibirica Mayr.; birch, Betula pendula Roth and $B$. pubescens Ehrh; and aspen, Populus tremula L.), wetland, open areas and rivers, encompassing some of the economically most valuable forest stands. Agricultural land is predominantly seen around the cities of Krasnoyarsk and Irkutsk. The overall topographic elevation of the study area is relatively low except in the southern part approaching the Mongolian border.

The climate of the boreal forest is highly continental with short, warm, and humid summers and long, extremely cold and dry winters. This biome as a whole receives low amounts of precipitation and daylight summer temperatures of $20^{\circ}$, occasionally up to $30^{\circ}$, are common. Under these circumstances the upper organic soil horizons can become desiccated which together with the higher temperatures and the low relative humidity create conditions favourable to fire (Kasischke 2000).

Weather patterns are considered to be the most important factor controlling fire occurrence (Stocks and Street 1983; Soja et al., 2004). Fire is a natural disturbance factor which occurs regularly in the boreal forest of Siberia with the area burned being about $35000 \mathrm{~km}^{2} \mathrm{yr}^{-1}$ on average $(0.6 \%$ of the forested area) (Shvidenko and Nilsson 1999). Much of the floristic diversity and many mosaic vegetation patterns within the boreal forest are directly attributable to recurring fires. The boreal forest biome is composed of a few plant species. In fact, eight tree species make up about $83 \%$ of all Siberian forests (Shvidenko and Nilsson 1994, Wirth 2005). In Siberia, early successional deciduous species, such as birch and aspen, are later succeeded by conifers, such as spruce. Although there are also early successional conifers such as Scots Pine and larch, the aspen-birch-spruce successional sequence is the most common over Siberia (Pastor et al. 1999). Coniferous species are the dominant species throughout Siberia. Larch is the main species in Central Siberia, followed by pine and deciduous species (mainly birch) (Table 1). 


\subsection{Data}

The main dataset used in this study is Moderate Resolution Imaging Spectroradiometer (MODIS)/Terra fAPAR $1 \mathrm{~km}$ 8-day composites produced at Boston University (MOD15_BU fAPAR), which is a variant of the MODIS/Terra LAI/fAPAR product (MOD15A2, Collection 4. The standard MODIS/Terra product is called LAI/FPAR). A bug was found in the code generating Collection 4 MOD15A2 fAPAR product (MOD15_BU product 2005). In the operational code, a '+' was written to '-', so fAPAR under diffuse radiation was produced instead of fAPAR under direct solar radiation, as required by the product specifications. Therefore, the imagery used in this study is MOD15_BU fAPAR which is reprocessed MOD15A2 with a corrected direct radiation regime and meets the requirements of the MOD15A2 fAPAR product specifications (Knyazikhin et al. 1999). A total of 184 images were collected for the period January 2001 to December 2004.

The MODIS/Terra sensor acquires global daily morning satellite images on 36 spectral bands, seven of which are designed for the study of vegetation and land surfaces: blue $(459-479 \mathrm{~nm})$, green $(545-565 \mathrm{~nm})$, red $(620-670 \mathrm{~nm})$, near infrared (NIR: 841-875 nm), and shortwave infrared (SWIR1: 1230-1250 nm, SWIR2: 1628$1652 \mathrm{~nm}$, SWIR3: 2105-2155 nm). Daily global imagery is provided at spatial resolutions of $250 \mathrm{~m}$ (red and NIR) and $500 \mathrm{~m}$ (blue, green, SWIR1, SWIR2, SWIR3). The MOD15_BU fAPAR product is a $1 \mathrm{~km}$ global data product updated once every 8days, selecting the highest-quality maximum fAPAR value recorded in that period. It measures the proportion of available radiation in the photosynthetically active wavelengths (400 to $700 \mathrm{~nm})$ that a vegetation canopy absorbs. The MOD15_BU retrievals are performed using a three-dimensional radiative transfer algorithm (Myneni et al. 2002), which uses a look-up table (LUT) approach (Knyazikhin et al. 1998) to calculate the most probable values of fAPAR for each pixel. It uses as inputs atmospherically corrected Bidirectional Reflectance Factor (BRF) for each MODIS band (MOD09 Surface Reflectance), band uncertainties, sun-view geometries, and the MODIS Land Cover type product (MOD12Q1).

We used the Forest Disturbance Map (FDM), produced in the framework of the EU funded project Siberia-II (Schmullius and Hese 2002, Balzter et al. 2005), to select burned areas according to two criteria (see Section 2.3 Selection of test sites). The FDM is a GIS vector database which is provided in Albers Conical Equal Area projection with a pixel size of $926.625 \mathrm{~m}$. The FDM was produced by George et al. (2006) and is based on MODIS/Terra Nadir BRDF-Adjusted Reflectance 16-day composites (MOD43B4) (Schaaf et al. 2002) acquired for the summers 2001, 2002 and 2003. Two different approaches were used to identify the FDM burned areas. Approach one identifies land areas which were burned in the same year of image acquisition and involved implementing a NDVI differencing technique (Kasiscke et al. 1993). Approach two identifies disturbances created up to ten years prior to the image acquisition date and involved using the NDSWIR (Normalised Difference ShortWave InfraRed index) (Gerard et al. 2003). A land cover map was needed in the production of the FDM to provide a baseline showing the forest extent back to 1992. The IGBP DISCover land cover map derived from 1992 and 1993 AVHRR imagery (Loveland et al. 2000) was used to exclude the non-woody areas and hotspot (thermal anomalies) information was used to date the burned areas.

The GLC2000 Land Cover Map (GLC2000) was used to select burned area polygons as a function of their forest type (see section 2.3). GLC2000 was derived from 
SPOT4-VEGETATION data divided in two time-windows as follows: from March to November of year 1999 to produce the land cover classification, and from June to August of year 2000 for the burned area class updating (Bartalev et al. 2003a).

\subsection{Selection of test sites}

The aim was to build up a four year time series of fAPAR, starting with year 2001, with 2002 being the year of the fire. As post-fire dynamics depend on the interval of fire recurrence, sites affected by recurrent fires in a short period of time will have a different behaviour than those affected by a single fire. So sites which burned in year 2002 (first criteria) and which did not burn any other time in the period from 1992 to 2003 either wholly or partially (second criteria) were selected. Finally, only sites dominated by evergreen needle-leaf (ENL), deciduous needle-leaf (DNL) or deciduous broadleaf (DBL), as defined by GLC2000, were selected (Table 2) because these forest types are common in the study area. Distinguishing between forest types is important because of their different adaptations to fire (Wirth 2005; Table 1) and because physiological differences in assimilation rates, carbon allocation, and nutrient use efficiency influence $\mathrm{CO}_{2}$ uptake during photosynthesis (Larcher 1980). For example, model sensitivity analyses for 21 forest stands showed that uncertainty in leaf area index (LAI), which is used to calculate fAPAR, can cause net canopy assimilation to be in error by up to $42-70 \%$ depending on forest types (Bonan 1993). Publications referring to/dealing with the estimation of forest type specific fAPAR uncertainty have not been found. The first two criteria rely on information available from the FDM and the third criteria on the GLC2000. Only test sites dominated at least by $75 \%$ of the forest types under study were selected. The final number of test sites fulfilling the three criteria was fourteen: six for ENL, five for DNL and three for DBL (Figure 2; Table 3).

For each of the fourteen burned areas an undisturbed adjacent unburned control plot was selected representing the same forest type. The control plots were introduced to help separate inter-annual fAPAR variations caused by local climate from changes in fAPAR behaviour due to a burn. For a valid comparison, the control plot must have characteristics similar in terms of area covered, forest type and climatic conditions to the burned area which it is paired with. The GLC2000 map was used to ensure the control plots were taken from the same forest type. Climatic conditions were kept similar by minimising the distance between the burned area and its control plot. The distance between the burned area and control plot ranged from $2 \mathrm{~km}$ to $9 \mathrm{~km}$. The FDM and thermal anomalies data were used to verify that the control plots did not burn in the previous twelve years. To isolate patterns attributed to latitude the selected test sites were grouped into three $5^{\circ}$ latitudinal bands from $51^{\circ}$ to $65^{\circ} \mathrm{N}$.

\subsection{MOD15_BU fAPAR time series analysis}

The time-series analysis of fAPAR was conducted for each burned area and control plot with the aim of providing aggregated estimates of change (Slayback et al. 2003) and to test for statistical significance. The pre-fire year, 2001, was used to assess the adequacy of the selected unburned control plots. To evaluate the post-fire response of the different forest types and latitudinal regions several variables were used:

- The mean of 8-day fAPAR for each burned area and its associated control plot was calculated to visually examine the seasonal patterns of individual burns. An example is provided in Figure 3.

- The mean and standard deviation of annual fAPAR were derived according to forest type, disturbance status (i.e. burned or control) and latitudinal region. 
- $\triangle$ fAPAR was calculated as the difference between the mean annual fAPAR of the burned areas and the mean annual fAPAR of their associated control plots grouped according to forest type and latitudinal region.

A repeated-measures Analysis of Variance (ANOVA) with a between subjectsfactors design was used to evaluate the effect of the factors forest type and latitudinal band on $\triangle$ fAPAR calculated for the three years from the year 2002 of the fires. Repeated measures designs are those that contain a sequence of observations of each subject (i.e. three years of $\triangle$ fAPAR observations for the burned areas). In this kind of design there is more than one source of variability, in this case in burned area according to forest type, latitude and from year to year (Everitt 1995). The assumptions made in this analysis are that there are correlations between forest type and time, and between latitude and time and that the data satisfy the 'circularity' property. This means that the variance of the difference between measurements at different times (i.e. years) is constant. Because the fAPAR values were analysed over several years at the same forest stand polygons, a repeated measures design is an appropriate ANOVA model. In this model the random variation between repeated fAPAR observations within one polygon is assumed to be lower than new polygons randomly selected each year. The model for the repeated measures analysis of variance was defined as

$$
\Delta f A P A R_{i j k}=\mu+\alpha_{i}+\beta_{j}+(\alpha \beta)_{i j}+\omega_{i j}+\gamma_{k}+(\alpha \gamma)_{i k}+(\beta \gamma)_{j k}+(\alpha \beta \gamma)_{i j k}+\varepsilon_{i j k}
$$

where $\triangle f A P A R_{i j k}$ is the difference between fAPAR of a pair of burned and unburned forest polygons; $\mu$ is the overall mean; $\alpha_{i}$ is the forest type effect; $\beta_{j}$ is the latitude effect; $(\alpha \beta)_{i j}$ are forest type/latitude interactions; $\omega_{i j}$ is the between-polygon pair error term; $\gamma_{k}$ is the time effect (year) within polygon pairs; $(\alpha \gamma)_{i k}$ are forest type/time interactions; $(\beta \gamma)_{j k}$ are latitude/time interactions; $(\alpha \beta \gamma)_{i j k}$ are forest type/latitude/time interactions and $\varepsilon_{i j k}$ is the within-polygon-pair error term.

Using the statistical analysis of the two between-subjects factors (forest type and latitude) and the repeated factor (time) we tested if there are differences in $\triangle$ fAPAR among the three forest types, among the three latitudinal regions and along time. We also tested if significant interactions exist between forest type and latitude; forest type and time; latitude and time; and forest type, latitude and time. The null hypothesis was in all cases that $\triangle$ fAPAR does not differ among the forest types, the latitudinal regions or along time and that the interactions were not significant.

The ANOVA will only establish whether there are any significant differences on $\triangle$ fAPAR within the studied factors (forest type, latitude or time) or whether there are significant interactions among the factors. A multiple group comparison, i.e. the Bonferroni correction, was applied to isolate where significant differences exist between pairs. This method ensures that the overall type I error is controlled (Everitt 1995).

\section{Results}

We assessed the adequacy of the selected unburned control plots by comparing their pre-fire fAPAR values with those of the burned areas. A one-way ANOVA test indicated that there were not significant differences between burned areas and control plots for the different forest types the year before the fire. Due to the use of control plots it was possible to account for the influence of inter-annual variability and other environmental factors captured in these unburned areas (Goetz et al. 2006) (Figure 3). 
Annual mean fAPAR for the burned areas and control plots grouped in terms of forest types and latitudinal bands are shown in Figures 3 and 4 respectively for the three years of observation. Fire effects on fAPAR are evident for the ENL forest type while there is little or no effect for the DBL forest type. The standard deviation (error bars) indicates that the variation in the measurements is higher for the ENL and DNL forest types than for the DBL forest type. When grouped according to latitude a clear pattern can be observed of increasing fAPAR with decreasing latitude, and the effects of fire on fAPAR are evident for every latitudinal region (Figure 5). The standard deviation indicates that the variation in the measurements is higher for the lower latitudinal region than for the upper and middle latitudinal regions.

$\triangle$ fAPAR in Table 4 quantifies the change in fAPAR undergone after fire by the different forest types. The ENL forest type is the most affected by fire experiencing a decrease in fAPAR of 0.096 the year of the fire (2002), which represents a $23.6 \%$ drop in the mean annual fAPAR with respect to the control plots. The DNL forest type experienced a decrease in fAPAR of 0.042 and the DBL forests a decrease of 0.01 representing a $16.3 \%$ and $3.3 \%$ drop in mean annual fAPAR with respect to the control plots, respectively. The relative difference in $\triangle$ fAPAR ( $\% \triangle$ fAPAR) between forest types is maintained in the subsequent years. Table 4 also shows $\triangle$ fAPAR grouped according to latitudinal region. fAPAR decreases in all latitudinal bands, but no clear patterns can be seen except that in the lower latitudes $\triangle$ fAPAR appears to be slightly larger and to vary less with time.

The results of the ANOVA analysis are shown in Table 5. The small p-value associated with forest type $(\mathrm{p}<0.01)$ indicates that there are significant differences in $\triangle$ fAPAR among the three forest types, i.e. the magnitude of the drop in fAPAR after fire depends on forest type, and hence the factor forest type plays the most important role in explaining the differences between the means in $\triangle$ fAPAR. Further analyses were done to test whether significant differences between the different levels of the factor forest type exist. Figure 6 shows the results of the Bonferroni test carried out on the factor forest type. The mean $\triangle$ fAPAR for the DNL and DBL forest types differs significantly from the ENL forest type.

The results of the ANOVA analysis also indicate that $\triangle$ fAPAR is not significantly different among the three latitudinal regions. Another important result is that there are significant interactions between forest type and latitude $(p<0.05)$. This means that the effects of forest type on $\triangle$ fAPAR also depends on latitude. This interaction between forest type and latitude could not be studied further because of the lack of all combinations since not all the forest types were present in all the latitudinal regions (e.g. the DBL forest type is not present in the upper latitudinal region). Also, $\triangle$ fAPAR is not significantly different for the three years of observations $(p>0.05)$, and there are no significant interactions between the two main factors (forest type and latitude) and time. This implies that for at least the first two years after a fire $\triangle$ fAPAR does not change.

\section{Discussion}

Due to the harsh climate conditions regeneration in the boreal forest is very slow; burned areas can take 60-100 years to regenerate to mature forests (Schulze et al. 2005). We observed a difference of MODIS fAPAR between latitudinal regions, namely a decrease in annual fAPAR with increasing latitude, which is due to the shortening of the growing season towards the north, and decreasing vegetation activity. 
Satellite-derived fAPAR has not been used in previous published studies of forest regeneration after fire, since fAPAR is mainly seen as an intermediate variable for calculation of net primary production (Myneni et al. 2003). However, we can compare the fAPAR results with previous studies of NPP. Whether NPP for different boreal forest types differs and in which direction is subject to dispute in the literature. Schulze et al. (1999) reported the same annual NPP values for ENL and DNL boreal forests (NPP $=123 \mathrm{gC} \mathrm{m}^{-2} \mathrm{y}^{-1}$ ), while Lloyd (1999) found that NPP was higher for the DBL $\left(228 \mathrm{gC} \mathrm{m}^{-2} \mathrm{y}^{-1}\right)$ than for the ENL forest type $\left(120 \mathrm{gC} \mathrm{m}^{-2} \mathrm{y}^{-1}\right)$. Yet, Potter et al. (1993) found higher values for ENL forest $\left(226 \mathrm{gC} \mathrm{m}^{-2} \mathrm{y}^{-1}\right)$ than for DNL forest (153 gC $\left.\mathrm{m}^{-2} \mathrm{y}^{-1}\right)$. These estimates were calculated using different forest types, study regions (boreal North America, Europe, Asia), and stand ages, which is the most likely explanation for the observed differences.

Our results from the analysis of MODIS fAPAR data suggest that the three forest types included in the analysis differ in their fAPAR activity and show characteristic fAPAR trajectories in the first few years following the fire. The ENL forest type has the highest mean annual fAPAR, followed by the DBL and the DNL forest types (Fig. 4). Post-fire fAPAR is most strongly affected in the ENL forest type (Figure 4, Table 4) followed by the DNL forest type, with no apparent change for the DBL forest type. This is partially confirmed by the statistical results showing significant differences in $\triangle$ fAPAR between the ENL and the two deciduous forest types (DBL and DNL) (Figure 6). These results confirm the suggested link between fire intensity and forest type: broad-leaved deciduous species tend to sustain fires of lower intensity than needle-leaved species (Dyrness et al. 1986). The finding that fAPAR of the ENL forest type is more affected by fire than that of the DNL forest type is thought to be related to the fact that larch (Larix sp.), a deciduous needle-leaf species commonly found in the study area, is less conductive for intense crown fires because it forms relatively open pure stands which lack understory fuels (Soja et al. 2004), which are associated with high severity in boreal forests (Cumming 2001). Another explanation for this phenomenon might be that $P$. sylvestris, which is the main ENL forest type in the study area, occurs on edaphically drier sites more prone to fire than typical larch sites with more fine-textured soils and underlying permafrost (Wirth 2005). Moreover, pine stands are more prone to crown fires than deciduous forests. The later usually attain surface fires and only under extreme weather conditions will be affected by crown fires (Rowe and Scotter 1973, Van Wagner 1983).

The temporal dynamics of $\triangle \mathrm{fAPAR}$ either for the different forest types or latitudinal regions show little difference and variability (Table 4). Moreover, the ANOVA test (Table 5) indicates that time is not a significant factor and that there are no interactions between time and the two main factors (forest type and latitude). These two facts may indicate that the $\triangle$ fAPAR caused by fire remains almost constant during the initial years following a fire. For the year 2002, when the fires happened, the annual fAPAR is composed of an average of both pre- and post-fire measurements. The inability to detect significant $\triangle$ fAPAR differences between 2002 and 2003 suggests that in most cases the fires took place at the beginning of the summer or that the areas were affected by low severity fires.

Some methodological considerations should be discussed in more detail. First, there are uncertainties in the calculation of fAPAR. The MODIS Land Cover product (MOD12Q1) is used to define the canopy radiation regime of the six biomes included in the calculation of fAPAR: grasses and cereal crops, shrubs, broadleaf crops, savannas, broadleaf forests, and needle-leaf forests. Biome misclassification in the MODIS land cover map is likely to introduce errors in the derived fAPAR, which may affect the 
analysis of fAPAR time-series. Second, the ratio of direct to total incident solar radiation (FDIR) is a very important variable in calculating fAPAR and changes with atmospheric conditions. Aerosols and clouds affect the FDIR and thus fAPAR. MODIS fAPAR is calculated assuming that the incident solar radiation consists solely of direct beam radiation. This assumption, together with the limitations in the atmospheric correction procedure used for MODIS data, is likely to produce some uncertainties in the MODIS fAPAR (Tian et al. 2004). This includes the potential of noise contamination of the fAPAR time series due to cloud effects during some acquisitions since no filtering was done to minimize such effects. Third, the GLC2000 land cover map used to identify the forest types of the burned areas and their control plots contains both classification and aggregation errors like all classified maps. It is difficult to assess the classification accuracy of pixels classified using satellite data over large areas due to the high structural and compositional variability within biomes (Xiao and Moody 2004). For example, a comparison of GLC2000 used in this analysis with the Swansea land cover map of Siberia based on MODIS imagery of 2002 (Skinner and Luckman 2004) highlighted confusion between broadleaf forest and cropland. These disagreements could be caused by (i) genuine land cover changes, (ii) misclassification, or (iii) misregistration. Seven originally selected burned areas were investigated closer by comparing the GLC2000 and Swansea land cover map classes for the selected areas. Four of the seven burned areas classified as broadleaved forest by the GLC2000 map were croplands or a mixture of other categories according to the Swansea land cover map. Of the seven DBL sites originally selected based on GLC2000, three remained after checking their land cover with Landsat TM imagery. Finally, we have to critically discuss why post-fire annual fAPAR values are greater than zero. A contributing factor is the coarse resolution of the satellite data together with the comparatively small size of some of the burned areas. In fact, seven of the fourteen selected burned areas are smaller than 20 pixels $\left(<20 \mathrm{~km}^{2}\right)$, containing a high number of boundary pixels which are likely to represent a mixture of burned and unburned vegetation. Thus, the fAPAR decrease following a fire is underestimated because of mixed burned/unburned boundary pixels and potential remaining patches of unburned trees in the centre of the fire scar. When selecting the burned areas the main constraint was found to be the prewildfire forest type. Most of the burned areas are smaller than $20 \mathrm{~km}^{2}$ because only burned areas containing more than $75 \%$ of one of the selected forest types were selected. Bigger burned areas usually contain several land cover types. Within our 3.2 million $\mathrm{km}^{2}$ study area we did not have enough large burned areas (i.e. sample size too small) representative of the forest types under study. Also although the larger study areas might appear more attractive, the problem with those is that they often contain pockets of surviving forest which do not always appear on the burned area product.

The study presented here is the first analysis of post-fire fAPAR time-series data from MODIS. The main results suggest that (i) the forest types exhibit characteristic fAPAR change trajectories shortly after the fire, (ii) the differences are related to the leaf habit, deciduous or evergreen, (iii) fAPAR changes are not significantly different among the latitudinal regions, and (iv) the small variability observed among the three years of observations indicates that fAPAR varies very little in the first years following a fire.

\section{Acknowledgements}

We thank Ranga Myneni and Wenze Yang from Boston University for re-processing and providing the MOD15_BU fAPAR data set. This work would not have been possible without the contribution and invaluable help of 1 Charles George, Matthias 
Monreal, Clare Rowland, Tim Jupp and Diane Unwin.

\section{References}

ARSENEAULT, D., 2001, Impact of fire behaviour on postfire forest development in a homogeneous boreal landscape. Canadian Journal of Forest Research, 31, 1367-1374.

BABINTSEVA, R.M. and TITOVA, Y.V., 1996, Effects of fire on the regeneration of Larch forests in the Lake Baikal Basin. In Fire in Ecosystems of Boreal Eurasia, J.G. Goldammer and V.V. Furyaev (eds), pp. 358-365 (Boston: Kluwer Academic Publishers).

BALZTER, H., GERARD, F.F., GEORGE, C.T., ROWLAND, C.S., JUPP, T.E., MACALLUM, I., SHVIDENKO, A., NILSSON, S., SUKHININ, A., ONUCHIN, A. and SCHMULLIUS, C., 2005, Impact of the arctic oscillation pattern on interannual forest fire variability in central Siberia. Geophysical Research Letters, 32, doi:10.1029/2005GL022526.

BARTALEV, S.A., BELWARD, A.S., ERCHOV, D.V. and ISAEV, A.S., 2003a, The land cover map of Northern Eurasia: method, product and initial users' feedback. Global Land Cover 2000. Available online at http://wwwgvm.jrc.it/glc2000/publications.htm (accessed 3 March 2005).

BARTALEV, S.A., BELWARD, A.S., ERCHOV, D.V. and ISAEV, A.S., 2003b, A new SPOT4-VEGETATION derived land cover map of Northern Eurasia. International Journal of Remote Sensing, 24, 1977-1982.

BERGERON, Y. and DANSEREAU, P.R., 1993, Predicting the composition of Canadian southern boreal forest in different fire cycles. Journal of Vegetation Science, 4, 827-832.

BONAN, G.B., 1993, Importance of Leaf Area Index and forest type when estimating photosynthesis in boreal forests. Remote Sensing of Environment, 43, 303-314.

CHAPIN III, F.S., STURM, M., SERREZE, M.C., MCFADDEN, J.P., KEY, J.R., LLOYD, A.H., MCGUIRE, A.D., RUPP, T.S., LYNCH, A.H., SCHIMEL, J.P., BERINGER, J., CHAPMAN, W.L., EPSTEIN, H.E., EUSKIRCHEN, E.S., HINZMAN, L.D., JIA, G., PING, C.-L., TAPE, K.D., THOMPSON, C.D.C., WALKER, D.A. and WELKER, J.M., 2005, Role of land-surface changes in Arctic summer warming. Science, 310, 657-660

CUMMING, S.G., 2001, Forest type and wildfire in the Alberta Boreal mixed wood: What do fires burn?. Ecological Applications, 11, 97-110.

DE GRANDPRE, L., MORISSETTE, J. and GAUTHIER, S., 2000, Long-term post-fire changes in the northeastern boreal forest of Quebec. Journal of Vegetation Science, 11, 791-800.

DIAZ-DELGADO, R., SALVADOR, R. and PONS, X., 1998, Monitoring of plant community regeneration after fire by remote sensing. In Fire management and landscape ecology, L. Trabaud (ed), pp. 315-324 (Fair-field, WA: International Association of Wildland Fire).

DIAZ-DELGADO, R. and PONS, X., 2001, Spatial patterns of forest fires in Catalonia (NE of Spain) along the period 1975-1995. Analysis of vegetation recovery after fire. Forest Ecology and Management, 147, 67-74.

DIAZ-DELGADO, R., LLORET, F. and PONS, X., 2003, Influence of fire severity on plant regeneration by means of remote sensing imagery. International Journal of Remote Sensing, 24, 1751-1763.

DYRNESS, C.T., VIERECK, L.A. and VAN CLEVE, K., 1986, Fire in taiga communities of interior Alaska. In Forest ecosystems in the Alaskan taiga: a synthesis 
of structure and function, K. Van Cleve, F.S. Chapin III, P.W. Flanagan, L.A. Viereck and C.T. Dyrness (eds), pp. 74-88 (New York: Springer-Verlag).

ECE/FAO (Economy Commission for Europe/Food and Agricultural Organization of the United Nations), 1985, The Forest Resources of the ECE Region (Europe, USSR, North America). ECE/FAO/27, Geneva.

ENVIRONMENT CANADA, (1995), The state of Canada's climate: monitoring change and variability. SOE Report No. 95-1, pp. 52. Ottawa, Canada. Cited in STOCKS, B.J., FOSBERG, M.A., LYNHAM, T.J., MEARNS, L., WOTTON, B.M., YANG, Q., JIN, J-Z., LAWRENCE, K., HARTLEY, G.R., MASON, J.A. and MCKENNEY, D.W.,1998, Climate change and forest fire potential in Russian and Canadian boreal forests. Climatic Change, 38, 1-13.

EUGSTER, W., ROUSE, W.R., PIELKE, R.A.Sr., MCFADDEN, J.P., BALDOCCHI, D.D., KITTEL, T.G.F., CHAPIN III, F.S., LISTON, G.E., VIDALE, P.L., VAGANOV, E. and CHAMBERS, S.D., 2000, Land-atmosphere energy exchange in Arctic tundra and boreal forest: available data and feedbacks to climate. Global Change Biology, 6 (suppl. 1), 84-115.

EVERITT, B.S., 1995, The analysis of repeated measures: a practical review with examples. The Statistician, 44, 113-135.

FIORELLA, M. and RIPPLE, W.J., 1993, Analysis of conifer forest regeneration using Landsat Thematic Mapper data. Photogrammetric Engineering and Remote Sensing, 59, 1383-1388.

FLANNIGAN, M.D. and VAN WAGNER, C.E., 1991, Climate change and wildfire in Canada. Canadian Journal of Forest Research, 21, 66-72.

FORTIN, M.J., PAYETTE, S. and MARINEAU, K., 1999, Spatial vegetation diversity index along a postfire successional gradient in the northern boreal forest. Ecoscience, 6, 204-213.

FOSBERG, M.A., GOLDAMMER, J.G., RIND, D. and PRICE, C., 1990, Global change: effects on forest ecosystems and wildfire severity. In Fire in the tropical biota. Ecosystem processes and global challenges, J.G. Goldammer (ed), pp. 463-486 (Berlin: Ecological Studies 84, Springer-Verlag).

FRA (Global forest resources assessment), 2000, Main report. Available online at http:// www.fao.org/forestry/site/fra2000report/en (accessed 18 July 2006).

FRENCH, N.H., KASISCHKE, E.S., JOHNSON, R.D., BOURGEAU-CHAVEZ, L.L., FRICK, A.L. and USTIN, S.L., 1996, Estimating fire-related carbon flux in Alaskan boreal forests using multi-sensor remote sensing data. AGU Chapman Conference on Biomass Burning and Climate Change. Available online at http://www.cstars.ucdavis.edu/papers/pdf/frenchetal1996a.pdf (accessed 6 March 2006).

FURYAEV, V.V., VAGANOV, E.A., TCHEBAKOVA, N.M. and VALENDIK, E.N., 2001, Effects of fire and climate on successions and structural changes in the Siberian boreal forest. Eurasian Journal of Forest Research, 2, 1-15.

GEORGE, C.T., ROWLAND, C., GERARD, F.F., BALZTER, H., 2006, Retrospective mapping of burnt areas in Central Siberia using A Modification of the Normalised Difference Water Index. Remote Sensing of Environment, 104, 346-359.

GERARD, F., PLUMMER, S., WADSWORTH, R., FERRERUELA, A., ILIFFE, L., BALZTER, H. and WYATT, B., 2003, Forest fire scar detection in the Boreal forest with multitemporal SPOT-VEGETATION data. IEEE Transactions on Geoscience and Remote Sensing, 41, 2575-2585. 
GOETZ, S.J., FISKE, G.J. and BUNN, A.G., 2006, Using satellite time-series data sets to analyze fire disturbance and forest recovery across Canada. Remote Sensing of Environment, 101, 352-365.

HENRY, M.C. and HOPE, A.S., 1998, Monitoring post-burn recovery of chaparral vegetation in southern California using muti-temporal satellite data. International Journal of Remote Sensing, 19, 3097-3107.

HICKE, J.A., ASNER, G.P., KASISCHKE, E.S., FRENCH, N.H.F., RANDERSON, J.T., COLLATZ, G.J., STOCKS, B.J., TUCKER, C.J., LOS, S.O. and FIELD, C.B., 2003, Postfire response of North American boreal forest net primary productivity analyzed with satellite observations. Global Change Biology, 9, 1145-1157.

JAKUBAUSKAS, M.E., LULLA, K.P., and MAUSEL, P.W., 1990, Assessment of vegetation change in a fire-altered forest landscape. Photogrammetric Engineering and Remote Sensing, 56, 371-377.

JOHNSTONE, J.F., CHAPIN III, F.S., FOOTE, J., KEMMET, S., PRICE, K. and VIERECK, L., 2004, Decadal observations of the tree regeneration following fire in boreal forests. Canadian Journal of Forest Research, 34, 267-273.

JUPP, T.E., TAYLOR, C.M., BALZTER, H. and GEORGE, C.T., 2006, A statistical model linking Siberian forest fire scars with early summer rainfall anomalies. Geophysical Research Letters, 33, L14701, doi: 10.1029/2006GL026679.

KNYAZIKHIN, Y., MARTONCHIK, J.V., MYNENI, R.B., DINER, D.J. and RUNNING, S.W., 1998, Synergistic algorithm for estimating vegetation canopy leaf area index and fraction of absorbed photosynthetically active radiation from MODIS and MISR data. Journal of Geophysical Research, 103, 32,257-32,275.

KNYAZIKHIN, Y., GLASSY, J., PRIVETTE, J.L., TIAN, Y., LOTSCH, A., ZHANG, Y., WANG, Y., MORISETTE, J.T., VOTAVA, P., MYNENI, R.B., NEMANI, R.R. and RUNNING, S.W., 1999, MODIS Leaf Area Index (LAI) and Fraction of Photosynthetically Active Radiation Absorbed by Vegetation (FPAR) Product (MOD15) Algorithm Theoretical Basis Document. Available online at http://eospso.gsfc.nasa.gov/atbd/modistables.html (accessed 1 July 2004).

KASISCHKE, E.S. and FRENCH, N.H.F., 1997, Constraints on using AVHRR composite index imagery to study patterns of vegetation cover in boreal forests. International Journal of Remote Sensing, 18, 2403-2426.

KASISCHKE, E.S., 2000, Boreal ecosystems in the Global Carbon Cycle. In: Fire, climate change and carbon cycling in the boreal forest (ed. Kasischke ES, Stocks BJ), pp. 19-30. Ecological studies series, Springer-Verlag.

KASISCHKE, E.S., FRENCH, N.H.F., HARRELL, P., CHRISTENSEN, N.L.J., USTIN, S.L. and BARRY, D., 1993, Monitoring of wildfires in boreal forests using large area AVHRR NDVI composite image data. Remote Sensing of Environment, 45, 61-71.

LARCHER, W., 1980, Physiological plant ecology, 2nd Ed (Berlin: Springer-Verlag).

LLOYD, J., 1999, The $\mathrm{CO}_{2}$ dependence of photosynthesis, plant growth responses to elevated $\mathrm{CO}_{2}$ concentrations and their interaction with soil nutrient status, II.

Temperate and boreal forest productivity and the combined affects of increasing $\mathrm{CO}_{2}$ concentrations and increased nitrogen deposition at a global scale. Functional Ecology, 13, 439-459.

LOVELAND, T.R., REED, B.C., BROWN, J.F., OHLEN, D.O., ZHU, Z., YANG, L. and MERCHANT, J.W., 2000, Development of a global land cover characteristics database and IGBP DISCover from $1 \mathrm{~km}$ AVHRR data. International Journal of Remote Sensing, 21 (6-7), 1303-1330. 
MCGUIRE, A.D., CHAPIN III, F.S., WALSH, J.E. and WIRTH, C., 2006, Integrated regional changes in Arctic climate feedbacks: Implications for the global climate system. Annual Review of Environment and Resources, 31, 61-91.

MARCHETTI, M., RICOTTA, C. and VOLPE, F., 1995, A qualitative approach to the mapping of post-fire regrowth in Mediterranean vegetation with Landsat TM data. International Journal of Remote Sensing, 16, 2487-2494.

MERONI, M., MOLLICONE, D., BELELLI, L., MANCA, G., ROSELLINI, S., STIVANELLO, S., TIRONE, G., ZOMPATI, R., TCHEBAKOVA, N., SCHULZE, E.D., and VALENTINI, R., 2002, Carbon and water exchanges of regenerating forests in central Siberia. Forest Ecology and Management, 169, 115-122.

MOD15_BU product, 2005, Declaration of the bug in Collection 4 MOD15A2 fAPAR product. Climate and Vegetation Research Group, Boston University. Available online at ftp://primavera.bu.edu/pub/datasets/MODIS/readme.pdf (accessed 6 March 2005).

MYNENI, R.B., HOFFMAN, S., KNYAZIKHIN, Y., PRIVETTE, J.L., GLASSY, J., TIAN, Y., WANG, Y., SONG, X., ZHANG, Y., SMITH, G.R., LOTSCH, A., FRIEDL, M., MORISETTE, J.T., VOTAVA, P., NEMANI, R.R. and RUNNING, S.W., 2002, Global products of vegetation leaf area and fraction absorbed PAR from year one of MODIS data. Remote Sensing of Environment, 83, 214- 231.

MYNENI, R., KNYAZIKHIN, Y., GLASSY, J., VOTAVA, P. and SHABANOV, N., 2003, User's guide FAPAR, LAI (ESDT: MOD15A2) 8-day Composite. NASA MODIS Land Algorithm. Available online at http://cybele.bu.edu/modismisr/products/modis/userguide.pdf (accessed 1 July 2004)_

PASTOR, J., COHEN, Y. and MOEN, R., 1999, Generation of spatial patterns in Boreal forest landscapes. Ecosystems, 2, 439-450.

PAYETTE, S., 1992, Fire as controlling process in the North American boreal forest. In A systems analysis of the global boreal forest, H.H. Shugart, R. Leemans and G.B. Bonan (eds), pp. 144-165 (Cambridge, UK: Cambridge University Press).

PELTZER, D.A., BAST, M.L., WILSON, S.D. and GERRY. A.K., 2000, Plant diversity and tree responses following contrasting disturbances in boreal forest. Forest Ecology and Management, 127, 191-203.

POTTER, C.S., RANDERSON, J.T., FIELD, C.B., MATSON, P.A., VITOUSEK, P.M., MOONEY, H.A. and KLOOSTER, S.A., 1993, Terrestrial ecosystem production: a process model based on global satellite and surface data. Global Biogeochemical Cycles, 7, 811-841.

RIAÑO, D., CHUVIECO, E., USTIN, S., ZOMER, R., DENNISON, P., ROBERTS, D. and SALAS, J., 2002, Assessment of vegetation regeneration after fire through multitemporal analysis of AVIRIS images in the Santa Monica Mountains. Remote Sensing of Environment, 79, 60-71.

RIAÑO, D., MORENO RUIZ, J.A., ISIDORO, D. and USTIN, S.L., 2007, Spatial and temporal patterns of burned area at global scale between 1981-2000 using NOAANASA Pathfinder. Global Change Biology, 13, 40-50.

ROJKOV, V.A., EFREMOV, D., NILSSON, S., SEDYKH, V.N., SHVIDENKO, A.Z., SOKOLOV, V. and WAGNER, V.B., 1996, Siberian landscape classification and a digitized map of Siberian landscapes. WP-96-111. International Institute for Applied Systems Analysis, Laxenburg, Austria.

ROWE, J.S. and SCOTTER, G.W., 1973, Fire in the boreal forest. Quaternary Research, 3, 444-464.

SCHAAF, C.B., GAO, F., STRAHLER, A.H., LUCHT, W., LI, X., TSANG, T., STRUGNELL, N.C., ZHANG, X., JIN, Y., MULLER, J.P., LEWIS, P., BARNSLEY, 
M., HOBSON, P., DISNEY, M., ROBERTS, G., DUNDERDALE, M., DOLL, C., D'ENTREMONT, R., HU, B., LIANG, S. and PRIVETTE, J.L., 2002, First Operational BRDF, Albedo and Nadir Reflectance Products from MODIS. Remote Sensing of Environment, 83, 135-148.

SCHIMMEL, J. and GRANSTRÖM, A., 1996, Fire severity and vegetation response in the boreal Swedish forest. Ecology, 77, 1436-1450.

SCHMULLIUS, C., HESE, S., and SIBERIA-II Team, 2002, SIBERIA-II: Sensor systems and data products for greenhouse gas accounting. In Proceedings of 19 DFD Nutzerseminar, Oberpfaffnehofen, Jena, 2002, pp. 173-180. Available online at http:// www.caf.dlr.de/caf/aktuelles/veranstaltungen/nutzerseminar/dfd 19/publikationen/pa pers/schmullius.pdf (accessed 2 May 2007)

SCHROEDER, D. and PERERA, A.H., 2002, A comparison of large-scale spatial vegetation patterns following clearcuts and fires in Ontario's boreal forests. Forest Ecology and Management, 159, 217-230.

SCHULZE, E.D., LLOYD, J., KELLIHER, F.M., WIRTH, C., REBMANN, C., LUHKER, B., MUND, M., KNOHL, A., MILYUKOVA, I.M., SCHULZE, W., ZIEGLER, W., VARLANGIN, A.B., SOGACHEV, A.F., VALENTINI, R., DORE, S., GRIGORIEV, S., KOLLE, O., PANFYOROV, M.I., TCHEBAKOVA, N. and VYGODSKAYA, N.N., 1999, Productivity of forests in the Eurosiberian boreal region and their potential to act as a carbon sink - a synthesis. Global Change Biology, 5, 703-722.

SCHULZE, E.D., WIRTH, C., MOLLICONE, D. and ZIEGLER, W., 2005, Succession after stand replacing disturbances by fire, wind throw, and insects in the dark Taiga of Central Siberia. Oecologia, 146, 77-88.

SHVIDENKO, A. and NILSSON, S., 1994, What do we know about the Siberian forests?. Ambio, 23, 396-404.

SHVIDENKO, A. and NILSSON, S., 1999, Phytomass, increment, mortality and carbon budget of Russian forests. Interim Report (IR-98-105). International Institute for Applied Systems Analysis, Laxenburg, Austria.

SKINNER, L. and LUCKMAN, A., 2004, Introducing a land cover map of Siberia derived from MERIS and MODIS data. In Proceedings of International Geoscience and Remote Sensing Symposium, Anchorage, Alaska, IEEE (Ed.), 2004, pp. 223-226.

SLAYBACK, D.A., PINZON, J.E., LOS, S.O. and TUCKER, C.J., 2003, Northern hemisphere photosynthetic trends 1982-99. Global Change Ecology, 9, 1-15.

SOJA, A.J., SUKHININ, A.I., CAHOON, J.R., SHUGART, H.H. and STACKHOUSEJr, P.W., 2004, AVHRR-derived fire frequency, distribution and area burned in Siberia. International Journal of Biometeorology, 25, 1939-1960.

SONG, C., WOODCOCK, C.E. and LI, X., 2002, The spectral/temporal manifestation of forest succession in optical imagery. The potential of multitemporal imagery. Remote Sensing of Environment, 82, 285-302.

STEYAERT, L.T., HALL, F.G. and LOVELAND, T.R., 1997, Land cover mapping, fire regeneration, and scaling studies in the Canadian boreal forest with $1 \mathrm{~km}$ AVHRR and Landsat TM data. Journal of Geophysical Research - Atmospheres, 102(D24), 29581-29598.

STOCKS, B.J., FOSBERG, M.A., LYNHAM, T.J., MEARNS, L., WOTTON, B.M., YANG, Q., JIN, J-Z., LAWRENCE, K., HARTLEY, G.R., MASON, J.A. and MCKENNEY, D.W., 1998, Climate change and forest fire potential in Russian and Canadian boreal forests. Climatic change, 38,1-13.

STOCKS, B.J. and STREET, R.B., 1983, Forest fire weather and wildfire occurrence in the boreal forest of northwestern Ontario. In Resources and dynamics of the boreal 
zone, R.W. Wein, R.R. Riewe and I.R. Methven (eds), pp. 249-265 (Ottawa: Association of Canadian Universities Northern Studies).

TIAN, Y., DICKINSON, E., ZHOU, L., ZENG, X., DAI, Y., MYNENI, R.B., KNYAZIKHIN, Y., ZHANG, X., FRIEDL, M., WU, W. and SHAIKH, M., 2004, Comparison of seasonal and spatial variations of leaf area index and fraction of absorbed photosynthetically active radiation from Moderate Resolution Imaging Spectroradiometer (MODIS) and Common Land Model. Journal of Geophysical Research, 109 (D01103), doi:10.1029/2003JD003777.

USTIN, S.L. and XIAO, Q.F., 2001, Mapping successional boreal forest in interior central Alaska. International Journal of Remote Sensing, 22, 1779-1797.

VALENTINI, R., DORE, S., MARCHI, G., MOLLICONE, D., PANFYOROV, M., REBMANN, C., KOLLE, O. and SCHULZE, E.D., 2000, Carbon and water exchanges of two contrasting central Siberia landscape types: regenerating forest and bog. Functional Ecology, 14, 87-96.

VAN WAGNER, C.E., 1983, Fire behaviour in northern conifer forests and shrublands. In The role of fire in northern circumpolar ecosystems, R.W. Wein and D.A. MacLean (eds), pp. 65-80 (Wiley, New York: SCOPE 18).

VIEDMA, O., MELIA, J., SEGARRA, D. and GARCIA-HARO, J., 1997, Modelling rates of ecosystem recovery after fires using Landsat TM data. Remote Sensing of Environment, 61, 383-398.

VINE, P. and PUECH, C., 1999, Cartography of post-fire forest regeneration by coupling a spectral mixture model with a vegetation regrowth model. Canadian Journal of Remote Sensing, 25, 152-159.

WIRTH, C., 2005, Fire regime and tree diversity in Boreal forests: implications for the carbon cycle. Ecological Studies, 176, 309-344

WOTTON, B.M. and FLANNIGAN, M.D., 1993, Length of the fire season in a changing climate. Forestry Chronicle, 69, 187-192.

XIAO, J. and MOODY, A., 2004, Trends in vegetation activity and their climatic correlates: China 1982 to 1998. International Journal of Remote Sensing, 25, 5669-5689. 


\section{Tables}

Table 1 Distribution of major tree species over forested area in the Central Siberian region. Forested area is expressed in thousand square kilometres (Shvidenko and Nilsson, 1994; Wirth et al., 2005).

\begin{tabular}{cccl}
\hline Genus & Forested area & Species & Fire adaptation \\
\hline Conifers & & & \\
\hline Spruce & 124 & Picea obovata & Avoider \\
Cedar & 235 & Pinus sibirica & Avoider \\
Fir & 94 & Abies sibirica & Avoider \\
Pine & 321 & Pinus sylvestris & Resister \\
Larch & 1028 & Larix sibirica & Resister \\
Broadleaf & & & Invader \\
Birch & 264 & Betula pendula & Endurer \\
Aspen & 48 & Betula pubescens &
\end{tabular}


Table 2 The GLC2000 land cover forest classes used in this study and their definition (Bartalev et al., 2003b).

GLC2000 class

Definition

Forest

Tree canopy cover is $>20 \%$ and height $>5 \mathrm{~m}$

Evergreen needle-leaf (ENL)

Deciduous needle-leaf (DNL)

Deciduous broadleaf (DBL)
The genera Picea and/or Abies and/or Pinus account for at least $80 \%$ of the area covered by trees

The genus Larix accounts for at least $80 \%$ of the area covered by trees

The genera Betula and/or Populus are dominant, though other broadleaf trees occur in small numbers 
Table 3 Number of selected burned areas and control plots and respective total area $\left(\mathrm{km}^{2}\right)$ per forest type and latitudinal region.

\begin{tabular}{lccc}
\hline & $\mathrm{N}^{\circ}$ burned areas & \multicolumn{2}{c}{ Total size $\left(\mathrm{km}^{2}\right)$} \\
\cline { 2 - 4 } & & Burned areas & Control plots \\
\hline Forest type & 6 & 83 & 74 \\
\hline Evergreen needle-leaf (ENL) & 5 & 152 & 119 \\
Deciduous needle-leaf (DNL) & 3 & 82 & 65 \\
Deciduous broadleaf (DBL) & & & 100 \\
\hline Latitudinal region & 8 & 170 & 62 \\
\hline Lower $\left(51^{\circ}-55^{\circ}\right)$ & 3 & 74 & 96 \\
Middle $\left(56^{\circ}-60^{\circ}\right)$ & 3 & 72 & \\
Upper $\left(61^{\circ}-65^{\circ}\right)$ & & & \\
\hline
\end{tabular}


the mean annual fAPAR values of the burned areas. The $\% \triangle \mathrm{fAPAR}$ is calculated with respect to the mean annual fAPAR of the control plots.

\begin{tabular}{lcccccc}
\hline & \multicolumn{3}{c}{$\Delta$ fAPAR } & \multicolumn{3}{c}{$\% \Delta$ fAPAR } \\
\cline { 2 - 7 } & 2002 & 2003 & 2004 & 2002 & 2003 & 2004 \\
\hline Forest Type & & & & & & \\
\hline Evergreen needle-leaf (ENL) & -0.096 & -0.089 & -0.106 & -23.6 & -23.8 & -27.4 \\
Deciduous needle-leaf (DNL) & -0.042 & -0.052 & -0.039 & -16.3 & -21.3 & -16.2 \\
Deciduous broad-leaf (DBL) & -0.010 & -0.015 & -0.009 & -3.3 & -5.1 & -3.0 \\
Latitude & & & & & & \\
\hline Low $\left(51^{\circ}-55^{\circ}\right)$ & -0.075 & -0.073 & -0.075 & -19.1 & -20.0 & -20.1 \\
Middle $\left(56^{\circ}-60^{\circ}\right)$ & -0.044 & -0.039 & -0.048 & -14.2 & -13.7 & -16.6 \\
Upper $\left(61^{\circ}-65^{\circ}\right)$ & -0.030 & -0.046 & -0.036 & -15.0 & -24.0 & -19.5 \\
\hline
\end{tabular}


'forest type' and 'latitude' as the between subject factors and 'time' with respect to burn as within subject factor. Pvalue $(* *<0.05)$

\begin{tabular}{ccccc}
$\begin{array}{c}\text { Degrees of } \\
\text { freedom }\end{array}$ & $\begin{array}{c}\text { Sum of } \\
\text { squares }\end{array}$ & $\begin{array}{c}\text { Mean } \\
\text { squares }\end{array}$ & F-value & p-value \\
\hline
\end{tabular}

Between subjects

$\begin{array}{lccccc}\text { Forest type } & 2 & 494.9406 & 247.4703 & 11.39 & 0.004^{* *} \\ \text { Latitude } & 2 & 95.0485 & 47.5242 & 2.19 & 0.175 \\ \text { Forest type : Latitude } & 1 & 129.9248 & 129.9248 & 5.98 & 0.040^{* *} \\ \text { Residual error } & 8 & 173.8410 & 21.7301 & & \end{array}$

\begin{tabular}{lccccc}
\hline Within subjects & \multicolumn{3}{l}{} \\
\hline Time & 2 & 0.4776 & 0.2388 & 0.10 & 0.903 \\
Forest type : Time & 4 & 13.4235 & 3.3559 & 1.44 & 0.267 \\
Latitude : Time & 4 & 4.0983 & 1.0246 & 0.44 & 0.778 \\
Forest type : Latitude : & 2 & 0.9965 & 0.4982 & 0.21 & 0.809 \\
Time & & 37.3260 & 2.3329 & & \\
Residual error & 16 & & & & \\
\hline
\end{tabular}

Figures 


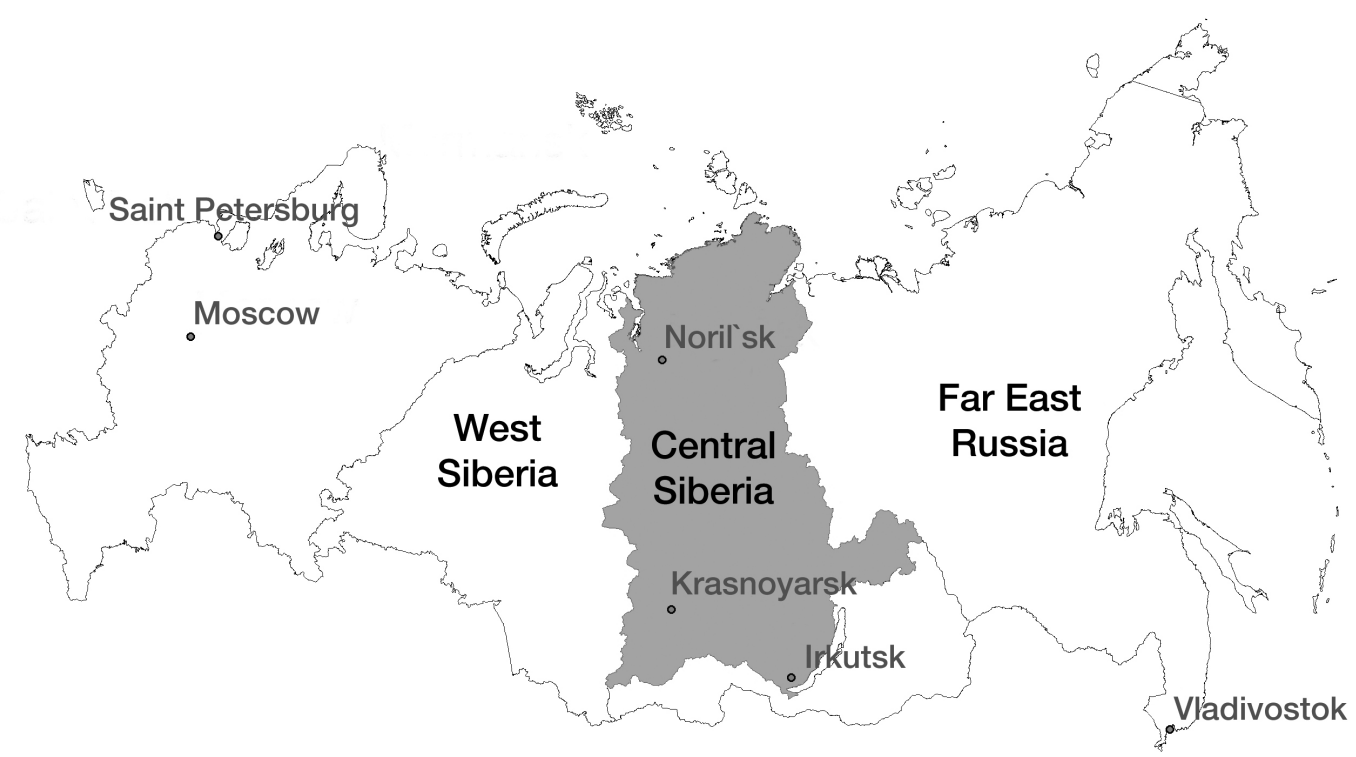

Figure 1. Regions of Siberia with the study area highlighted. 


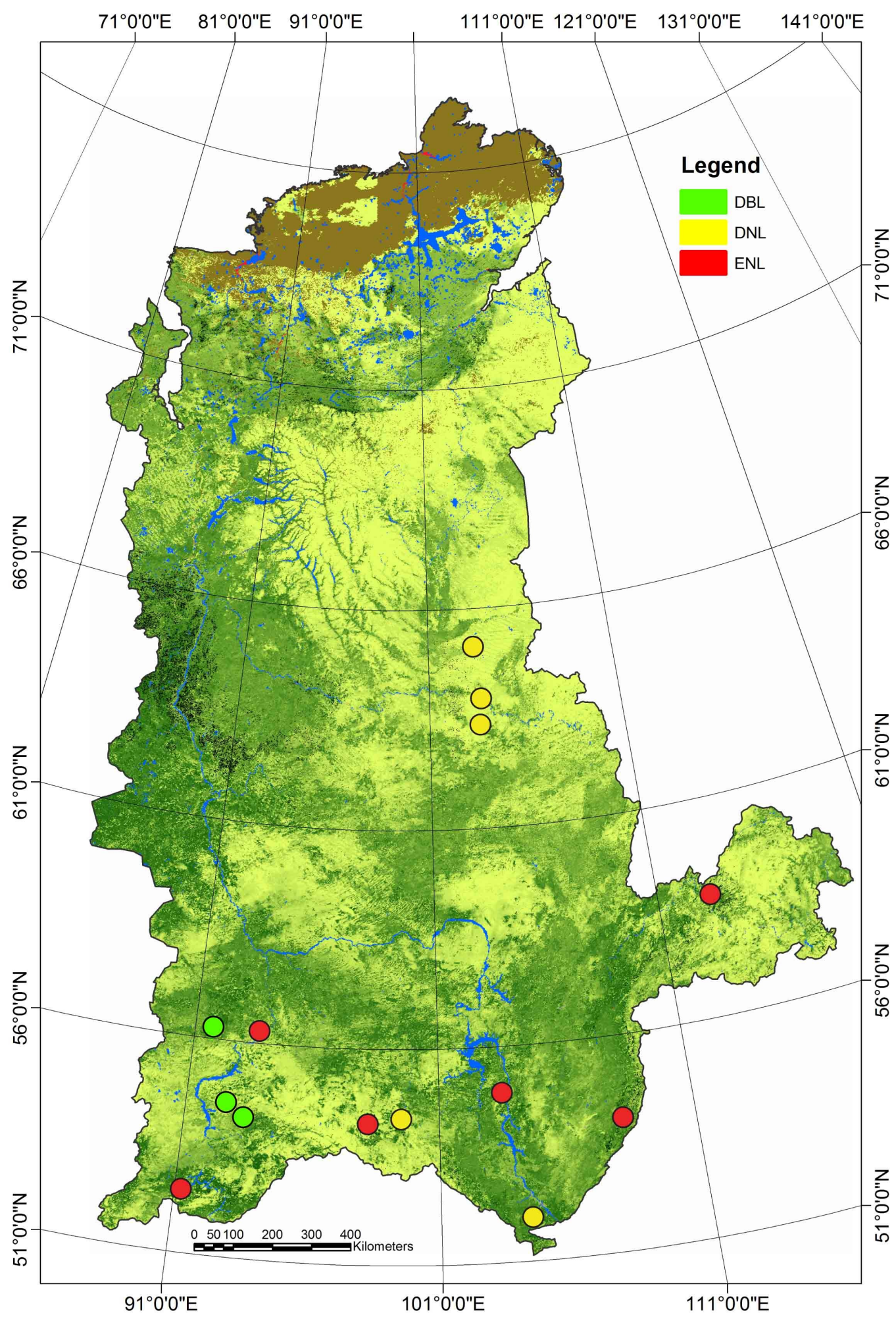

Figure 2. fAPAR image of the study area indicating the location of the test sites. Each dot locates a burned area and its respective control plot. The distance between the burned area and control plot ranged from $2 \mathrm{~km}$ to $9 \mathrm{~km}$. Test sites representing evergreen needle-leaf forests (ENL) are shown in red, deciduous needle-leaf forests (DNL) in yellow and deciduous broadleaf forests (DBL) in green. 


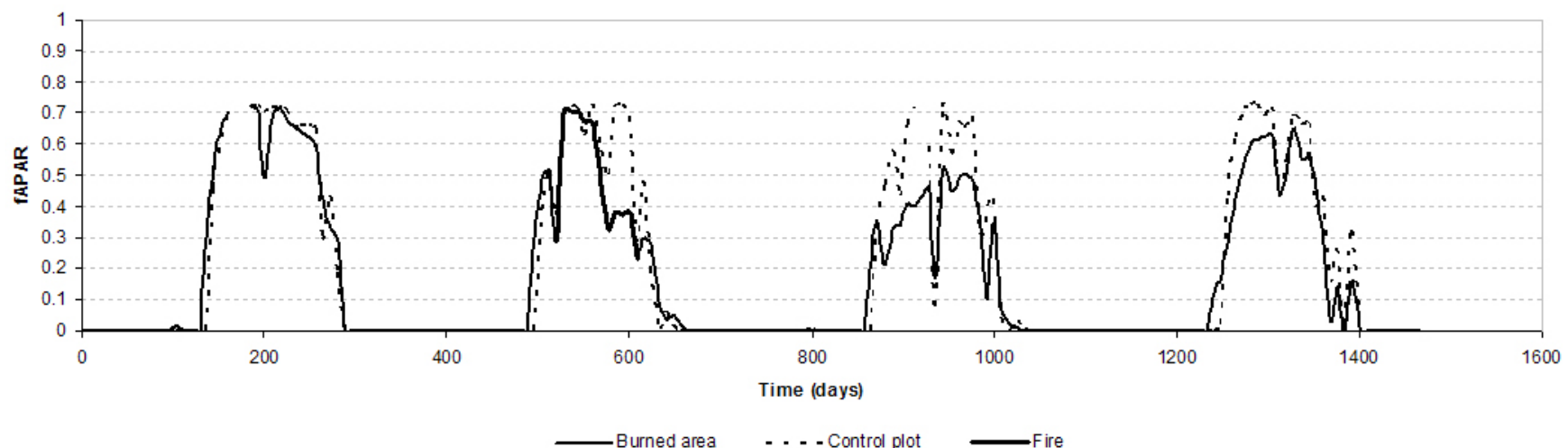

Figure 3. fAPAR for one burned area and its respective control plot along four years, including the year before the fire. The coarse black line indicates the duration of the fire as determined by thermal anomalies. Shifts in the starting point of the growing season and variations in FAPAR caused by changes in local climate can be separated from the changes caused by fire. 


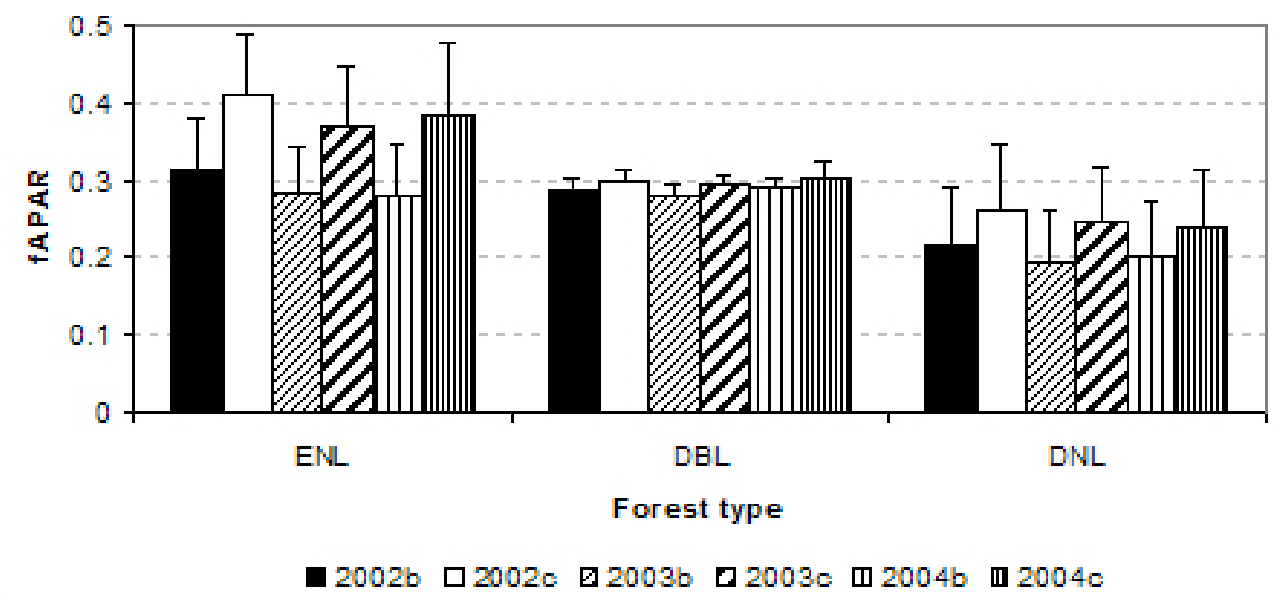

Figure 4. Mean annual fAPAR of the burned areas and their respective control plots of the evergreen needle-leaf (ENL), deciduous needle-leaf (DNL) and deciduous broadleaf (DBL) forest types for three consecutive years starting with 2002 the year of the fire event. The error bars show the standard deviation. 2002c, 2003c and 2004c represent the control plots. $2002 \mathrm{~b}, 2003 \mathrm{~b}$ and $2004 \mathrm{~b}$ represent the burned areas. 


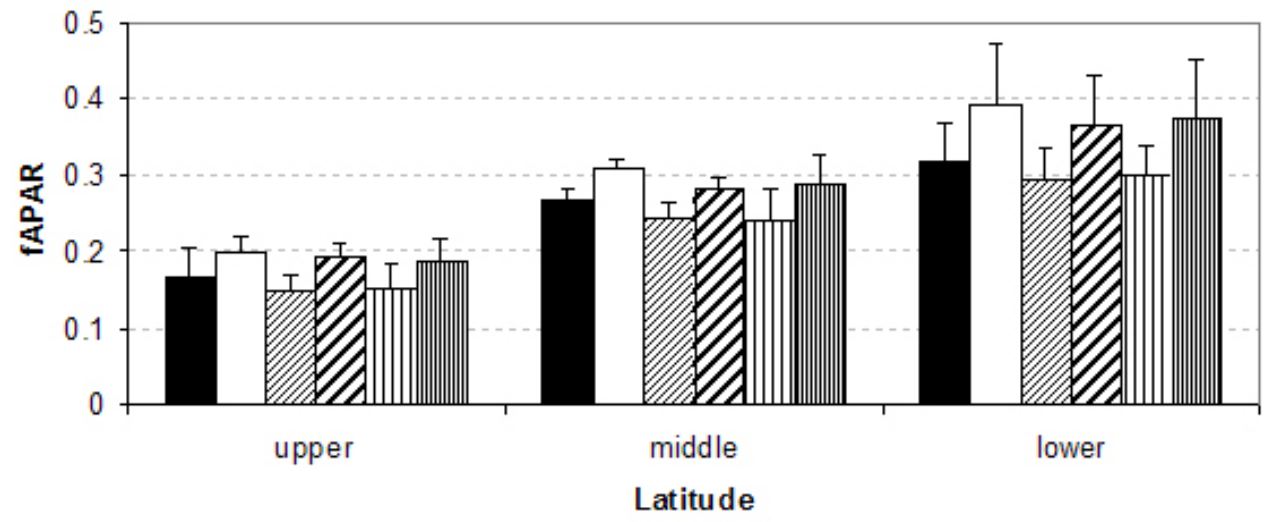

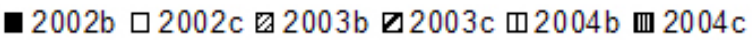

Figure 5. Mean annual fAPAR of the burned areas and their respective control plots of the upper $\left(61^{\circ}-65^{\circ}\right)$, middle $\left(56^{\circ}-60^{\circ}\right)$ and lower $\left(51^{\circ}-55^{\circ}\right)$ latitudinal regions for three consecutive years starting with 2002 the year of the fire event. The error bars show the standard deviation. 2002c, 2003c and 2004c represent the control plots. 2002b, 2003b and $2004 \mathrm{~b}$ represent the burned areas. 


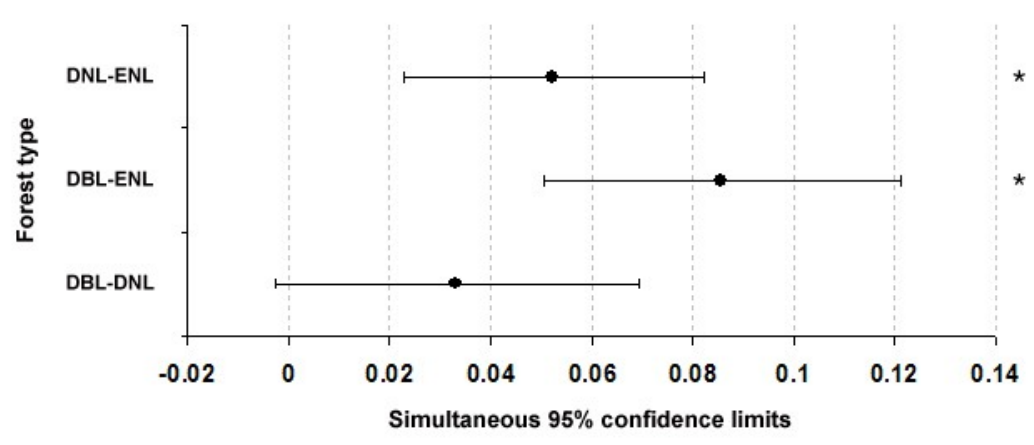

Figure 6. Results of the Bonferroni correction for the between factor 'forest type' showing the $95 \%$ simultaneous confidence intervals. Pairwise comparisons with intervals excluding zero $(*)$ are significant. The forest types included in the analysis are the evergreen needleleaf (ENL), the deciduous needle-leaf (DNL) and the deciduous broadleaf (DBL). 